Part of Journal of Research of the National Bureau of Standards, Volume 22, April 1939

\title{
HEAT AND FREE ENERGY OF FORMATION OF WATER AND OF CARBON MONOXIDE *
}

\author{
By Frederick D. Rossini
}

\section{ABSTRACT}

Thermodynamic data were combined to yield values for the heats and free energies, per mole, of the following reactions, with each substance in the thermodynamic standard state:

$\mathrm{H}_{2}(\mathrm{~g})+1 / 2 \mathrm{O}_{2}$ (g) $=\mathrm{H}_{2} \mathrm{O}$ (liq), $\Delta H^{\circ}{ }_{298.16}=-285,795 \pm 40$ int. $\mathrm{j}(-68,318.1 \pm 9.6$ cal), $\Delta F^{\circ}{ }_{298.16}=-237,163 \pm 47$ int. $j(-56,692.8 \pm 11.2$ cal $)$;

$\mathrm{H}_{2} \mathrm{O}$ (liq) $=\mathrm{H}_{2} \mathrm{O}(\mathrm{g}), \Delta H^{\circ}{ }_{298.16}=44,007 \pm 13$ int. $\mathrm{j}(10,519.7 \pm 3.1 \mathrm{cal}), \Delta F^{\circ}{ }_{298.10}=$ $8597 \pm 4$ int. $\mathrm{j}(2055.1 \pm 1.0 \mathrm{cal})$

$\mathrm{H}_{2}(\mathrm{~g})+1 / 2 \mathrm{O}_{2}(\mathrm{~g})=\mathrm{H}_{2} \mathrm{O}(\mathrm{g}), \Delta \dot{H}^{\circ}{ }_{298.16}=-241,788 \pm 42$ int. $\mathrm{j}(-57,798.4 \pm 10.0$ cal), $\Delta F^{\circ}{ }_{298.16}=-228,566 \pm 47$ int. $\mathrm{j}(-54,637.7 \pm 11.2 \mathrm{cal})$;

$\mathrm{CO}(\mathrm{g})+1 / 2 \mathrm{O}_{2}(\mathrm{~g})=\mathrm{CO}_{2}(\mathrm{~g}), \Delta H^{\circ}{ }_{298.16}=-282,942 \pm 120$ int. $\mathrm{j}(-67,636.1 \pm 28.7$ cal), $\Delta F^{\circ}{ }_{298.10}=-257,069 \pm 121$ int. $\mathrm{j}(-61,451.2 \pm 29.0 \mathrm{cal})$;

$\mathrm{C}$ (c, graphite $)+1 / 2 \mathrm{O}_{2}(\mathrm{~g})=\mathrm{CO}(\mathrm{g}), \Delta H^{\circ}{ }_{298.10}=-110,413 \pm 129$ int. $\mathrm{j}(-26,393.8$ $\pm 30.8 \mathrm{cal}), \Delta F^{\circ}{ }_{298.16}=-137,158 \pm 133$ int. $\mathrm{j}(-32,787.0 \pm 31.8 \mathrm{cal})$

$\mathrm{H}_{2}(\mathrm{~g})+\mathrm{CO}_{2}(\mathrm{~g})=\mathrm{H}_{2} \mathrm{O}(\mathrm{g})+\mathrm{CO}(\mathrm{g}), \Delta H^{\circ}{ }_{298.16}=41,154 \pm 127$ int. $\mathrm{j}$ (9837.7 \pm 30.4 cal), $\Delta F^{\circ}{ }_{299.16}=28,504 \pm 130$ int. $\mathrm{j}(6813.8 \pm 31.1 \mathrm{cal})$;

$\mathrm{C}$ (c, graphite $)+\mathrm{CO}_{2}(\mathrm{~g})=2 \mathrm{CO}(\mathrm{g}), \Delta H^{\circ}{ }^{\circ 98.16}=172,529 \pm 244$ int. $\mathrm{j} \quad(41,242.3$ $\pm 58.4 \mathrm{cal}), \Delta F_{288.10}^{\circ}=119,911 \pm 248$ int. $\mathrm{j}(28,664.2 \pm 59.3 \mathrm{cal})$.

$\begin{array}{lr}\text { CONTENTS } & \text { Page } \\ \text { I. Introduction } & 407\end{array}$

II. Sources of the data; calculations

1. Values of $(d H / d P)_{T} \ldots$

2. Heat, entropy, and free energy of vaporization of water $\ldots$

3. Values of entropies

4. Values of $H^{\circ}{ }_{298.10}-H_{0}^{\circ}$

5. Heat and free energy of formation of water............ 410

6. Heat and free energy of combustion and formation of carbon monoxide....

7. Water-gas and producer-gas reactions

III. Summary

IV. References_........ 414

\section{INTRODUCTION}

This report presents values for the heat and free energy of formation of water and carbon monoxide and for the heat and free energy of the water-gas and producer-gas reactions. Values for these thermodynamic quantities were calculated from calorimetric data on the heats of combustion of hydrogen, carbon, and carbon monoxide and appropriate other new data on the entropies of the various substances involved, on the heat of vaporization of water, and on corrections to the ideal thermodynamic state.

* Presented before the Division of Physícal-Inorganic Chemistry at the meeting of the American Chemical Society in Baltimore, Md., A pril 3-7, 1939. 
For each reaction entirely in the gaseous phase, there was first calculated from calorimetric data the value of $\Delta H^{\circ}{ }_{298.18}$, which is the value of the change in heat content associated with the given reaction at $25^{\circ} \mathrm{C}$, with each reactant and product in the ideal state of unit fugacity ( 1 atmosphere). ${ }^{1}$ Then from the entropies of the various gases, which have been evaluated statistically by various investigators from spectroscopic and other molecular data, there was calculated the value of $\Delta S^{\circ}{ }_{298.18}$, which is the change in entropy associated with the given reaction at $25^{\circ} \mathrm{C}$, with each reactant and product in the ideal state of unit fugacity. These values for the change in heat content and entropy were then combined by means of the relation

$$
\Delta F=\Delta H-T \Delta S
$$

to yield the value of $\Delta F^{\circ}{ }_{288.10}$, which is the change in free energy associated with the given reaction at $25^{\circ} \mathrm{C}$, with each substance in the selected standard state.

To each value reported there is attached an estimate of the uncertainty. Where possible, this uncertainty was evaluated by a method previously described $[2] ;{ }^{2}$ in other cases conservative estimates of uncertainty were made.

The unit of energy used is the international joule, determined by standards of electromotive force and resistance maintained at this Bureau. Conversion to the conventional defined calorie was made by means of the factor $1 / 4.1833$.

For conversion of the statistically calculated values of entropies and heat contents to the units of energy used in this paper, the value of the gas constant, $R$, was taken as $8.3145 \pm 0.0006$ absolute $\mathrm{j}$ degree $\theta^{-1}$ mole ${ }^{-1}$, or $8.3128 \pm 0.0008$ int. $\mathrm{j}$ degree ${ }^{-1} \mathrm{~mole}^{-1}$, or $1.98714 \pm 0.00019$ cal degree $e^{-1} \mathrm{~mole}^{-1}$. (The derivation of the values of these constants will be discussed in a later report.)

\section{SOURCES OF THE DATA; CALCULATIONS}

\section{VALUES OF $(d H / d P)_{T}$}

In order to correct the values of $\Delta H$ obtained for 1 atmosphere to values of $\Delta H$ with each substance in the standard state, there are required values of $(d H / d P)_{T}$ for the gases at $25^{\circ} \mathrm{C}$ and 0 to 1 atmos. phere. ${ }^{3}$

For the gases (except water) involved in the present calculations, the values of $H^{P=0}-H^{P=1}$ at $25^{\circ} \mathrm{C}$ range from $-0.5 \mathrm{j} / \mathrm{mole}$ for $H_{2}(\mathrm{~g})$ to $41 \mathrm{j} / \mathrm{mole}$ for $\mathrm{CO}_{2}(\mathrm{~g})$. While the correction to zero pressure is not significant for hydrogen, and barely so for oxygen and carbon monoxide, the correction was made for all the gases for the sake of consistency.

In table 1 are given values of $H^{P=0}-H^{P=1}$ at $25^{\circ} \mathrm{C}$ for the gases, hydrogen, oxygen, carbon monoxide, carbon dioxide, and mixtures of oxygen and carbon dioxide. For hydrogen and carbon dioxide, the values were calculated by means of the Beattie-Bridgeman equation of state with the constants given by these authors [3, 4]. For oxygen

1 Following Lewis and Randall [1], the superscript zero attached to a symbol denotes the selected thermodynamic standard state, and the subscript denotes the absolute temperature to which it applies.

Figures in brackets indicate the literature references at the end of this paper.

The heat content of a gas in the ideal (hypothetical) standard state of unit fugacity of 1 atmosphere is the same as the heat content of the real gas at zero pressure. The standard state for a liquid or solid is taken as that of the real substance at a pressure of 1 atmosphere. 
and mixtures of oxygen and carbon dioxide, the values were calculated from the published data of Rossini and Frandsen [5] on $(d E / d P)_{T}$ at $28^{\circ} \mathrm{C}$ and their unpublished data on the $P-V-T$ relations of mixtures of oxygen and carbon dioxide [6], together with the temperature coefficient given by the Beattie-Bridgeman equation of state for conversion to $25^{\circ} \mathrm{C}$. For carbon monoxide, the value was obtained by extrapolation of values of $(d H / d P)_{T}$ calculated from values of $V$ and $T(d V / d T)_{P}$ given by Deming and Shupe [7] for 100, 75, 50, and 25 atmospheres.

For $\mathrm{H}_{2} \mathrm{O}(\mathrm{g})$ at $25^{\circ} \mathrm{C}$, the value of $H^{P=0}-H^{P=0.03122}$ was taken as $22.0 \pm 1.0 \mathrm{j} / \mathrm{mole}$, from unpublished calculations by C. H. Meyers of this Bureau. This value is substantially identical with that obtained by extrapolating values of $(d H / d P)_{T}$ for $\mathrm{H}_{2} \mathrm{O}(\mathrm{g})$ reported by Collins and Keyes [8]. The value for the vapor pressure of water at $25^{\circ} \mathrm{C}$ was taken as $0.031222 \pm 0.00020$ atmosphere [9].

TABLE 1.-Values ${ }^{a}$ of $H^{P=0}-H^{P=1}$ at $25^{\circ} C$

\begin{tabular}{|c|c|}
\hline Substance & $H^{\mathrm{P}-0}-H^{\mathrm{P}-1}$ \\
\hline $\begin{array}{l}\mathrm{H}_{2}(\mathrm{~g}) \\
\mathrm{O}_{2}(\mathrm{~g}) \\
\mathrm{CO}(\mathrm{g}) \\
\mathrm{CO}_{2}(\mathrm{~g}) \\
{\left[(1-x) \mathrm{O}_{2}+x \mathrm{CO}_{2}\right] \mathrm{b}(\mathrm{g})}\end{array}$ & $\begin{array}{c}j \text { mole } e^{-1} \\
-0.48 \\
8.06 \\
7.20 \\
41.4 \\
8.06+15.9 x+17.4 x^{2}\end{array}$ \\
\hline
\end{tabular}

a The uncertainty in these values is of the order of several percent.

- The symbol $x$ denotes the mole fraction of $\mathrm{CO}_{2}$.

2. HEAT, ENTROPY, AND FREE ENERGY OF VAPORIZATION OF WATER

The new calorimetric data of Osborne, Stimson, and Ginnings [10] yield ${ }^{4}$ for

$$
\begin{gathered}
\mathrm{H}_{2} \mathrm{O}(\mathrm{liq})=\mathrm{H}_{2} \mathrm{O}(\mathrm{g}) \\
\Delta H_{298.18}^{P=0.03122}=43,985 \pm 13 \text { int. j mole }{ }^{-1} .
\end{gathered}
$$

Conversion to the ideal standard state yields

$$
\Delta H_{298.16}^{\circ}=44,007 \pm 13 \text { int. } \mathrm{j} \text { mole }{ }^{-1} .
$$

For the entropy of the process,

$$
\Delta S_{288.16}^{P=0.03122}=147.521 \pm 0.044 \text { int. j deg }{ }^{-1} \text { mole }^{-1} .
$$

For $\mathrm{H}_{2} \mathrm{O}(\mathrm{g})$ at $25^{\circ} \mathrm{C}$ and a pressure of 0.031222 atmosphere,

$$
S_{\text {tdeal }}-S_{\text {real }}=0.058 \pm 0.002 \text { int. j deg }{ }^{-1} \text { mole }^{-1} \text {, }
$$

from unpublished calculations by C. H. Meyers. For the ideal gas at $25^{\circ} \mathrm{C}$, the entropy of compression to 1 atmosphere is

$S^{p=1}-S^{p=0.031222}=-R \ln [1 / 0.031222]$

$$
=-28.817 \pm 0.020 \text { int. } \mathrm{j} \mathrm{deg}^{-1} \text { mole }^{-1} \text {. }
$$

Combination of eq 5, 6, and 7 yields for the vaporization of water, according to eq 2 ,

$$
\Delta S_{298.18}^{\circ}=118.762 \pm 0.048 \text { int. j deg }{ }^{-1} \text { mole }^{-1} .
$$

\footnotetext{
1 mole of water is taken as $18.0162 \mathrm{~g}$ [20].
} 
For $\mathrm{H}_{2} \mathrm{O}(\mathrm{g})$ at $25^{\circ} \mathrm{C}$ and. a pressure of 0.031222 atmosphere, the unpublished calculations of C. H. Meyers yield

$$
F_{\text {ideal }}-F_{\text {real }}=4.7 \pm 1.2 \mathrm{j} \mathrm{mole}^{-1} \text {. }
$$

For the ideal gas at $25^{\circ} \mathrm{C}$, the free energy of compression to 1 atmosphere is

$F^{P=1}-F^{p=0.031222}=R T \ln [1 / 0.031222]=8592.2 \pm 3.0$ int. j mole ${ }^{-1}$.

For the vaporization of water at $25^{\circ} \mathrm{C}$ at its saturation pressure the change in free energy is zero:

$$
\Delta F_{298.16}^{P=0.031222}=0.0 \mathrm{j} \mathrm{mole} \mathrm{e}^{-1} \text {. }
$$

Combination of eq $9,9 a$, and $9 b$ yields for the vaporization of water, according to eq 2 ,

$$
\Delta F_{298.16}^{\circ}=8597 \pm 4 \text { int. } \mathrm{j} \mathrm{mole}{ }^{-1} \text {. }
$$

\section{VALUES OF ENTROPIES}

The values used for the entropies at $25^{\circ} \mathrm{C}$ are given in table 2 , where the sources are also indicated.

\begin{tabular}{|c|c|c|c|c|c|}
\hline Substance & \multicolumn{2}{|c|}{$S_{298.16}^{\circ}$} & \multicolumn{2}{|c|}{$H_{298.16}^{\circ}-H_{0}^{\circ}$} & $\begin{array}{l}\text { Source of } \\
\text { values }\end{array}$ \\
\hline $\begin{array}{l}\mathrm{C}(\mathrm{c}, \text { graphite }) \\
\mathrm{O}_{2}(\mathrm{~g}) \\
\mathrm{CO}_{2}(\mathrm{~g}) \\
\mathrm{CO}(\mathrm{g}) \\
\mathrm{H}_{2}(\mathrm{~g}) \\
\mathrm{H}_{2} \mathrm{O}(\mathrm{g}) \\
\mathrm{H}_{2} \mathrm{O} \text { (liq) }\end{array}$ & $\begin{array}{r}\text { int. } j \text { deg }^{-1} \text { mole } \\
5.712 \pm 0.100 \\
205.090 \pm .040 \\
213.729 \pm .040 \\
197.958 \pm .040 \\
130.644 \pm .020 \\
188.843 \pm .064 \\
70.081 \pm .080\end{array}$ & $\begin{array}{r}\text { cala deg-1 mo! } \text { med }^{-1} \\
1.365 \pm 0.024 \\
49.026 \pm .010 \\
51.091 \pm .010 \\
47.321 \pm .010 \\
31.230 \pm .005 \\
45.142 \pm .015 \\
16.752 \pm .019\end{array}$ & $\begin{array}{r}\text { int } f \text { mole }-1 \\
1053.8 \pm 12.5 \\
8653.6 \pm 3.0 \\
9370.6 \pm 4.0 \\
8670.7 \pm 3.0 \\
8466.6 \pm 2.0 \\
9905.6 \pm 4.0\end{array}$ & $\begin{array}{l}c^{c}{ }^{\mathrm{a}} \text { mole } \\
251.9 \pm 3.0 \\
2068.6 \pm 0.7 \\
2240.0 \pm 1.0 \\
2072.7 \pm 0.7 \\
2023.9 \pm .5 \\
2367.9 \pm 1.0\end{array}$ & $\begin{array}{l}\text { d }[11,12] \\
\text { d }[11,14] \\
{[15,16,17]} \\
{[18,19]} \\
\text { (b) } \\
\text { (c) }\end{array}$ \\
\hline
\end{tabular}

TABLE 2.-Values of entropies at $25^{\circ} \mathrm{C}$, and of heat contents at $25^{\circ} \mathrm{C}$ rejerred to the absolute zero

The calorie is defined as 4,1833 int. j.

b Unpublished value calculated by H. L. Johnston using the actual rotational lerels instead of those of a rigid rotator. The value obtained by adding to Gordon's [23] value of the entrops (calculated on the basis of a rigid rotator) the correction for rotational distortion evaluated by Wilson [24] is lower than the value calculated by Johnston by $0.038 \mathrm{j} \mathrm{deg}^{-1} \mathrm{~mole}^{-1}$.

- Calculated from eq 2 and 8 and the value for $\mathrm{H}_{2} \mathrm{O}(\mathrm{g})$.

d The values for the entropies and heat contents previously given [11] for $\mathrm{CO}_{2}$ and $\mathrm{O}_{2}$ differ (but not signiflcantly) from those given in this table, because of the change in the value taken for the gas constant $R$. How ever, no change occurs in the values of $\Delta S_{288.16}^{\circ}, \Delta F_{293.16}^{\circ}$, and $\Delta H_{0}^{\circ}$ previously given [11] for the formation of carbon dioxide from its elements.

\section{VALUES OF $H^{\circ}{ }_{298 \cdot 16}-H_{0}^{\circ}$}

For calculating values of $\Delta H_{0}^{\circ}$ from the values $\Delta H^{\circ}{ }_{298 \cdot 18}$, there are required values of $H_{298.16}^{\circ}-H_{0}^{\circ}$ for each of the substances involved in the reactions. These values and their sources are given in table 2.

\section{HEAT AND FREE ENERGY OF FORMATION OF WATER}

The data reported in 1931 [21] for the heat of combustion of hydrogen, together with a correction $(-3.6 \mathrm{j} / \mathrm{mole}$ in $\Delta H)$ to the ideal state of unit fugacity and a correction $(-9.5 \mathrm{j} / \mathrm{mole}$ in $\Delta H)$ for the change in the molecular weight (to $18.0162 \mathrm{~g}$ ) of water [20], yield for

$$
\begin{gathered}
\mathrm{H}_{2}(\mathrm{~g})+1 / 2 \mathrm{O}_{2}(\mathrm{~g})=\mathrm{H}_{2} \mathrm{O} \text { (liq) } \\
\Delta H^{\circ}{ }_{288.16}=-285,795 \pm 40 \text { int. j mole }{ }^{-1} .
\end{gathered}
$$


Combination of eq 2, 4, and 12 yields for

$$
\begin{gathered}
\mathrm{H}_{2}(\mathrm{~g})+1 / 2 \mathrm{O}_{2}(\mathrm{~g})=\mathrm{H}_{2} \mathrm{O}(\mathrm{g}) \\
\Delta H^{\circ}{ }_{298.16}=-241,788 \pm 42 \text { int. j mole }{ }^{-1} .
\end{gathered}
$$

Combination of eq 1 and 14 with the entropies of $\mathrm{H}_{2}(\mathrm{~g}), 1 / 2 \mathrm{O}_{2}(\mathrm{~g})$, and $\mathrm{H}_{2} \mathrm{O}(\mathrm{g})$ yields for eq 13 , the formation of gaseous water,

$$
\Delta F_{298.16}^{\circ}=-228,566 \pm 47 \text { int. } \mathrm{j} \mathrm{mole}{ }^{-1} \text {. }
$$

Combination of eq 2 and 10 with 13 and 15 yields, for eq 11, the formation of liquid water,

$$
\Delta F^{\circ}{ }_{298.18}=-237,163 \pm 47 \text { int. j mole }{ }^{-1} .
$$

\section{HEAT AND FREE ENERGY OF COMBUSTION AND FORMATION OF CARBON MONOXIDE}

The data reported in $1931[22]^{5}$ for the heat of combustion of carbon monoxide, together with a correction $(25.2 \mathrm{j} / \mathrm{mole}$ in $\Delta H)$ to the ideal state of unit fugacity and a correction $(-64.3 \mathrm{j} / \mathrm{mole}$ in $\Delta \mathrm{H})$ for the change in the molecular weight (to 44.010) of carbon dioxide (which determined the amount of reaction) [20], yield for

$$
\begin{gathered}
\mathrm{CO}(\mathrm{g})+1 / 2 \mathrm{O}_{2}(\mathrm{~g})=\mathrm{CO}_{2}(\mathrm{~g}) \\
\Delta H^{\circ}{ }_{298.16}=-282,942 \pm 120 \text { int. j mole }{ }^{-1} .
\end{gathered}
$$

The correction of the observed value of $\Delta H$ at 1 atmosphere to that at zero pressure was made in the following way. Examination of the calorimetric data on the heat of combustion indicated that the reaction which actually occurred in the calorimeter, on the average, was

$\mathrm{CO}(\mathrm{g}, 1 \mathrm{~atm})+0.89 \mathrm{O}_{2}(\mathrm{~g}, 1 \mathrm{~atm})=\left(\mathrm{CO}_{2}+0.39 \mathrm{O}_{2}\right)(\mathrm{g}, 1 \mathrm{~atm})$.

To the value of $\Delta H\left(-282,967 \pm 120 \mathrm{int} . \mathrm{j} /\right.$ mole of $\left.\mathrm{CO}_{2}\right)$ observed for this process were added the values of $\Delta H(-7.2,-7.2$, and $39.6 \mathrm{j}$, respectively) associated with the following three processes:

$$
\begin{gathered}
\mathrm{CO}(\mathrm{g}, 0 \mathrm{~atm})=\mathrm{CO}(\mathrm{g}, 1 \mathrm{~atm}) \\
0.89 \mathrm{O}_{2}(\mathrm{~g}, 0 \mathrm{~atm})=0.89 \mathrm{O}_{2}(\mathrm{~g}, 1 \mathrm{~atm}) \\
\left(\mathrm{CO}_{2}+0.39 \mathrm{O}_{2}\right)(\mathrm{g}, 1 \mathrm{~atm})=\left(\mathrm{CO}_{2}+0.39 \mathrm{O}_{2}\right)(\mathrm{g}, 0 \mathrm{~atm}) .
\end{gathered}
$$

Combination of eq 18 and the entropies of $\mathrm{CO}(\mathrm{g}), 1 / 2 \mathrm{O}_{2}(\mathrm{~g})$, and $\mathrm{CO}_{2}$ (g) with eq 1 yields for the combustion of carbon monoxide, eq 17 ,

$$
\Delta F^{\circ}{ }_{298 \cdot 18}=-257,069 \pm 121 \text { int. } \mathrm{j} \text { mole }{ }^{-1} .
$$

In a previous report [11] there was given for

$$
\begin{gathered}
\mathrm{C} \text { (c, graphite) }+\mathrm{O}_{2}(\mathrm{~g})=\mathrm{CO}_{2}(\mathrm{~g}) \\
\Delta{H^{\circ}}^{\circ}{ }_{298 \cdot 18}=-393,355 \pm 46 \text { int. j mole }{ }^{-1} \\
\Delta F^{\circ}{ }_{298 \cdot 18}=-394,228 \pm 58 \text { int. j mole }{ }^{-1} .
\end{gathered}
$$

\footnotetext{
- The three other modern determinations of the heat of combustion of carbon monoxide, by Awbery and Griffiths [25], Fenning and Cotton [26], and Roth and Banse [27], yield values in accord with eq 17 and 18 within their estimated limits of uncertainty, namely, $\pm 480, \pm 210$, and $\pm 840 \mathrm{j} / \mathrm{mole}$, respectively. See reference [28].
} 
Combination of eq 18,23, 25, and 26 with 17 and 24 yields for the formation of carbon monoxide from its elements in their standard states

$$
\begin{gathered}
\mathrm{C}(\mathrm{c} \text {, graphite })+1 / 2 \mathrm{O}_{2}(\mathrm{~g})=\mathrm{CO}(\mathrm{g}) \\
\Delta H^{\circ}{ }_{298 \cdot 16}=-110,413 \pm 129 \text { int. j mole }{ }^{-1} \\
\Delta{F^{\circ}}_{298 \cdot 16}=-137,158 \pm 133 \text { int. j mole }{ }^{-1} .
\end{gathered}
$$

7. WATER-GAS AND PRODUCER-GAS REACTIONS

Values of the heat and free energy of the water-gas reaction may be obtained by combining eq $13,14,15,17,18$, and 23 :

$$
\begin{aligned}
& \mathrm{H}_{2}(\mathrm{~g})+\mathrm{CO}_{2}(\mathrm{~g})=\mathrm{H}_{2} \mathrm{O}(\mathrm{g})+\mathrm{CO}(\mathrm{g}) \\
& \Delta H^{\circ}{ }_{298 \cdot 16}=41,154 \pm 127 \text { int. j mole } \\
& \Delta{F^{\circ}}^{\circ}{ }_{298 \cdot 16}=28,504 \pm 130 \text { int. j mole }{ }^{-1} .
\end{aligned}
$$

Similarly, from eq $17,18,23,24,25$, and 26 , there is obtained for the producer-gas reaction

$$
\begin{aligned}
& \mathrm{C}(\mathrm{c}, \text { graphite })+\mathrm{CO}_{2}(\mathrm{~g})=2 \mathrm{CO}(\mathrm{g}) \\
& \Delta H^{\circ}{ }_{298 \cdot 16}=172,529 \pm 244 \text { int. j mole }{ }^{-1} \\
& \Delta F^{\circ}{ }_{298 \cdot 16}=119,911 \pm 248 \text { int. j mole }{ }^{-1} .
\end{aligned}
$$

\section{SUMMARY}

A summary of all the values of $\Delta H^{\circ}{ }_{298 \cdot 16}$ and $\Delta F^{\circ}{ }_{298 \cdot 16}$ is given in table 3, together with values of $\Delta H_{0}^{\circ}$, calculated from the values of $\Delta H^{\circ}{ }_{298 \cdot 16}$ and the appropriate values of $H^{\circ}{ }_{298 \cdot 16}-H^{\circ}$ from table 2. 
TABLE 3.-Summary of thermodynamic values

\begin{tabular}{|c|c|c|c|c|c|c|}
\hline Reaction & $\Delta H^{\circ}$ & 8.16 & $\Delta F$ & 8.16 & & $I^{\circ} 0$ \\
\hline $\begin{array}{l}\mathrm{H}_{2}(\mathrm{~g})+1 / 2 \mathrm{O}_{2}(\mathrm{~g})=\mathrm{H}_{2} \mathrm{O}(\mathrm{liq}) \\
\mathrm{H}_{2} \mathrm{O}(\mathrm{liq})=\mathrm{H}_{2} \mathrm{O}(\mathrm{g}) \\
\mathrm{H}_{3}(\mathrm{~g})+1 / 2 \mathrm{O}_{2}(\mathrm{~g})=\mathrm{H}_{2} \mathrm{O}(\mathrm{g}) \\
\mathrm{CO}(\mathrm{g})+1 / 2 \mathrm{O}_{2}(\mathrm{~g})=\mathrm{CO}_{2}(\mathrm{~g})=\mathrm{CO}(\mathrm{g}) \\
\mathrm{C}(\mathrm{g}, \mathrm{graphite})+1 / 2 \mathrm{O}_{2}(\mathrm{~g})=\mathrm{CO} \\
\mathrm{H}_{2}(\mathrm{~g})+\mathrm{CO}_{2}(\mathrm{~g})=\mathrm{H}_{2} \mathrm{O}(\mathrm{g})+\mathrm{CO}(\mathrm{g}) \\
\mathrm{C}(\mathrm{c}, \text { graphite })+\mathrm{CO}_{2}(\mathrm{~g})=2 \mathrm{CO}(\mathrm{g}) \\
\mathrm{C}(\mathrm{c} \text {, graphite })+\mathrm{O}_{2}(\mathrm{~g})=\mathrm{CO}_{2}(\mathrm{~g})\end{array}$ & $\begin{array}{l}\text { int. } j \text { mole }-1 \\
-285,795 \pm 40 \\
44,007 \pm 13 \\
-241,788 \pm 42 \\
-282,942 \pm 120 \\
-110,413 \pm 129 \\
41,154 \pm 127 \\
172,529 \pm 244 \\
-393,355 \pm 46\end{array}$ & $\begin{array}{r}\text { cals mole }{ }^{-1} \\
-68,318.1 \pm 9.6 \\
10,519.7 \pm 3.1 \\
-57,798.4 \pm 10.0 \\
-67,636.1 \pm 28.7 \\
-26,393.8 \pm 30.8 \\
9,837.7 \pm 30.4 \\
41,242.3 \pm 58.4 \\
-94,029.8 \pm 11.0\end{array}$ & $\begin{aligned} \text { int. } j \text { mole-1 } \\
-237,163 \pm 47 \\
8,597 \pm 4 \\
-228,566 \pm 47 \\
-257,069 \pm 121 \\
-137,158 \pm 133 \\
28,504 \pm 130 \\
119,911 \pm 248 \\
-394,228 \pm 58\end{aligned}$ & $\begin{array}{r}\text { cals mole-1 } \\
-56,692.8 \pm 11.2 \\
2,055.1 \pm 1.0 \\
-54,637.7 \pm 11.2 \\
-61,451.2 \pm 29.0 \\
-32,787.0 \pm 31.8 \\
6,813.8 \pm 31.1 \\
28,664.2 \pm 59.3 \\
-94,238.5 \pm 13.9\end{array}$ & $\begin{array}{c}\text { int. } j \text { mole }-1 \\
-238,900 \pm 42 \\
-279,315 \pm 120 \\
-113,703 \pm 130 \\
40,415 \pm 127 \\
165,612 \pm 244 \\
-393,018 \pm 48\end{array}$ & \begin{tabular}{r}
\multicolumn{1}{c}{ cals $^{\text {mole }}$ mol $^{-1}$} \\
$-57,108.0 \pm 10.0$ \\
$-66,769.1 \pm 28.7$ \\
$-27,180.2 \pm 31.1$ \\
$9,661.0 \pm 30.4$ \\
$39,588.8 \pm 58.4$ \\
$-93,949.3 \pm 11.5$
\end{tabular} \\
\hline
\end{tabular}

a The calorie is defined as 4.1833 int. j. 


\section{REFERENCES}

[1] G. N. Lewis and M. Randall, Thermodynamics and the Free Energy of Chemical Substances (McGraw-Hill Book Co., New York, N. Y., 1923).

[2] F. D. Rossini, Chem. Rev. 18, 233 (1936).

[3] J. A. Beattie and O. C. Bridgeman, Proc. Am. Acad. Arts Sci. 63, 229 (1928).

[4] J. A. Beattie and O. C. Bridgeman, Phys. Rev. 32, 699 (1928).

[5] F. D. Rossini and M. Frandsen, BS. J. Research 9, 733 (1932) RP503.

[6] E. W. Washburn, BS. J. Research 10, 525 (1933) RP546.

[7] W. E. Deming and L. E. Shupe, Phys. Rev. 38, 2245 (1931).

[8] S. C. Collins and F. G. Keyes, Proc. Am. Acad. Arts Sci. 72, 283 (1938).

[9] N. S. Osborne and C. H. Meyers, J. Research NBS 13, 1 (1934) RP691.

[10] N. S. Osborne, H. F. Stimson, and D. C. Ginnings, Forthcoming paper in J. Research NBS.

[11] F. D. Rossini and R. S. Jessup, J. Research NBS 21, 491 (1938) RP1141.

[12] C. J. Jacobs and G. S. Parks, J. Am. Chem. Soc. 56, 1513 (1934).

[13] H. L. Johnston and M. L. Walker, J. Am. Chem. Soc. 55, 172 (1933); 5\%, $682(1935)$.

[14] L. S. Kassel, J. Am. Chem. Soc. 56, 1838 (1934).

[15] J. O. Clayton and W. F. Giauque, J. Am. Chem. Soc. 56, 2610 (1932); 57, 5071 (1933).

[16] L. S. Kassel, J. Chem. Phys. 1, 576 (1933).

[17] H. L. Johnston and C. O. Davis, J. Am. Chem. Soc. 56, 271 (1934).

[18] W. F. Giauque, J. Am. Chem. Soc. 52, 4816 (1930).

[19] H. L. Johnston and E. A. Long, J. Chem. Phys. 2, 389 (1934).

[20] G. P. Baxter, O. Hönigschmid, and P. Le Beau, J. Am. Chem. Soc. 60, 737 (1938).

[21] F. D. Rossini, BS. J. Research 6, 1 (1931); 7, 329 (1931).

[22] F. D. Rossini, BS. J. Research 6, 37 (1931); $\boldsymbol{7}, 329$ (1931).

[23] A. R. Gordon, J. Chem. Phys. 2, 65 (1934).

24] E. B. Wilson, Jr., J. Chem. Phys. 4, 526 (1936).

[25] J. H. Awbery and E. Griffiths, Proc. Roy. Soc. (London) [A] 141, 1 (1933).

[26] R. W. Fenning and F. T. Cotton, Proc. Roy. Soc. (London) [A] 141, 17 (1933).

[27] W. A. Roth and H. Banse, Arch. Eisenhutten 6, 43 (1932-33).

[28] F. R. Bichowsky and F. D. Rossini, Thermochemistry of the Chemical Substances, (Reinhold Publishing Corp., New York, N. Y., 1936).

Washington, January 20, 1939. 